\title{
Predicting biogas production using kinetic model for mesophilic and thermophilic temperature regimes: a theoretical approach
}

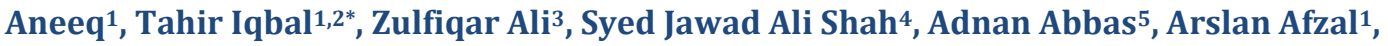 \\ Muhammad Jehanzeb Masud Cheema ${ }^{1,2}$ \\ ${ }^{1}$ Faculty of Agricultural Engineering \& Technology, PMAS Arid Agriculture University Rawalpindi, Pakistan \\ ${ }^{2}$ National Center of Industrial Biotechnology, PMAS Arid Agriculture University Rawalpindi, Pakistan \\ ${ }^{3}$ School of Chemical Engineering and Technology, Xian Jiaotong University, 710000, P.R China \\ ${ }^{4}$ National Laboratory of Solid-State Microstructure, Material Science, \& Engineering Department, Nanjing University, \\ 210093, P.R China \\ ${ }^{5}$ College of Engineering, Nanjing Agricultural University, P.R China
}

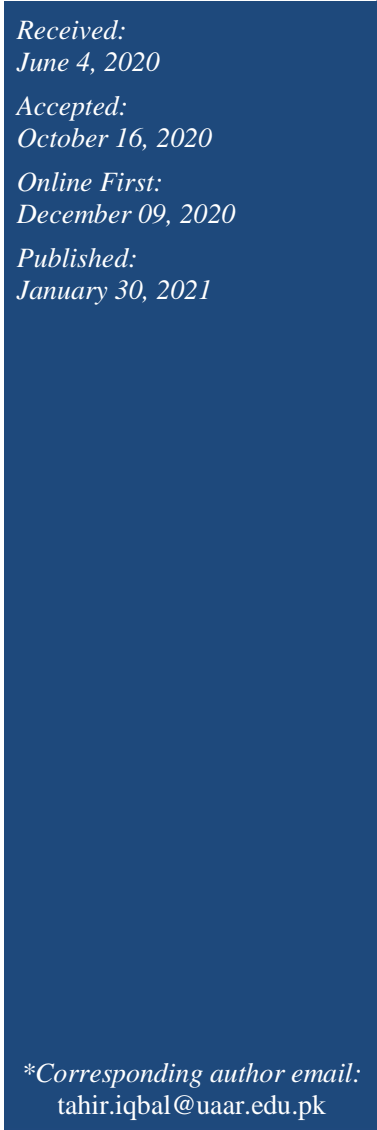

\begin{abstract}
Ever since global warming, largely caused by consumption of fossil fuels, has alarmed the scientists and policy makers, biomass has been gaining acceptance and currency as a means of sustainable energy generation. Biogas generation through anaerobic digestion of biomass is a promising technique of converting carbonaceous material into methane and carbon dioxide i.e major components of biogas. This work aims at determination of methane production rate based on kinetic study while taking into consideration temperature, total solids, volatile solids, residence time, and bacterial growth. We used banana waste including stem, fruit stem, peel and leaves as waste material and applied Chen \& Hashimoto kinetic model to measure the methane potential. The wet anaerobic digestion process digested the banana waste inside the bioreactor for 15 days of hydraulic retention time on mesophilic temperature regime $35-40^{\circ} \mathrm{C}$ and 10 days for thermophilic temperature regime $55-60^{\circ} \mathrm{C}$. The methane production was $14.6 \mathrm{~m}^{3} /$ day using $100 \mathrm{~kg} /$ day of banana waste. This showed a close accord to the already observed and published data based on total solid, volatile solid, carbon to nitrogen ratio and temperature.
\end{abstract}

Keywords: Agricultural Residue, Anaerobic Digestion, Banana Waste, Biogas, Kinetic Model

\section{How to cite this:}

Aneeq, Iqbal T, Ali Z, Shah SJA, Abbas A, Afzal A and Cheema MJM, 2021. Predicting biogas production using kinetic model for mesophilic and thermophilic temperature regimes: a theoretical approach. Asian J. Agric. Biol. 2021(1). DOI: https://doi.org/10.35495/ajab.2020.03.196

This is an Open Access article distributed under the terms of the Creative Commons Attribution 3.0 License. (https://creativecommons.org/licenses/by/3.0), which permits unrestricted use, distribution, and reproduction in any medium, provided the original work is properly cited.

\section{Introduction}

Climate change challenge has attracted the attention of policymakers worldwide towards sustainable, renewable and clean energy which is a prerequisite to slash down greenhouse gas emissions. Open field burning of agricultural residues is a common practice to eliminate crop waste after harvesting across many countries. This practice is detrimental to environment due to generation of higher NOx concentration and 
greenhouse gases emission. The detailed emission of different gaseous pollutants along with characteristics and environmental impacts from direct burning of valuable wastes have been reported by (Iqbal et al., 2019). In addition, various studies have revealed that agricultural residue carries promising potential of alternative energy generation owing to its carbon neutral nature, low prices, and abundant availability. These pros have attracted scientists' attention towards use of biomaterial for generation of clean energy to meet growing energy demands vis-à-vis preservation of the environment (Javed et al., 2016).

In 2015, COP 21 conference on climate change set a global target to contain global warming below $2^{\circ} \mathrm{C}$ by 2100 (FCCC, 2015). It has been projected that by 2040, 1.7 billion people will move to urban areas, adding up the energy demand by more than a quarter to present value (Capuano, 2018). There are number of factors prompting a shift from conventional energy sources to sustainable energy. Renewable energy is regarded as the key tool to overcome the energy demand by maintaining the temperature increase below $2{ }^{\circ} \mathrm{C}$ compared to pre-industrial revolution era. The renewable energy has many forms e.g. solar energy, wind energy, geothermal energy, torrefaction, and biogas generation through anaerobic digestion (AD).

Pakistan, being an agricultural country has tremendous potential of using agricultural waste for energy generation. According to our previous study the collective processing residues were estimate 25.271 million tons which have potential to generate 689.25 TWh annually. While the animal dung has potential of 4,761 to 5,554 MW electricity generation (Iqbal et al., 2018).

Banana is one of the major fruit crops in Pakistan. The annual production of banana is around 154,825 million tons with addition of 309650 million tons of banana organic waste (APP, 2016). The banana residue is enriched in organic composition and holds the fourth position as world's most produced commodity after rice, wheat, and apple (Khan et al., 2009). The existing utilization of banana waste in Pakistan is either open field burning or reincorporation into the soil. The farmers can use this abundant source as an organic fertilizer as well as biogas to meet the farm for production of on farm energy. Bhushan et al. (2019) critically reviewed the potential of energy from banana waste and analyzed different processing segments for effective conversion of banana waste to energy.
Biogas is produced by natural transformation of organic matter. This process has four-stage metabolic reactions; i) hydrolysis, ii) acidogenesis, iii) acetogenesis, and iv) methanogenesis (Kashyap et al., 2003 and Stams et al., 2005). The rate of reaction is influenced by multiple factors like temperature, $\mathrm{pH}$, geometry of the reactor and hydraulic retention time (Barros et al., 2010). The factors affecting the anaerobic digestion (AD) process of biowaste are mainly chemical composition, concentration of intermediate products, absence of oxygen, nutrient content, toxic compound, bioreactor design and stirring intensity (Khalid et al., 2011). The AD process is enhanced by the microbial transformation in the presence of water at $\mathrm{pH}$ around 6.5 to 7 . The microbial activity is greatly influenced by $\mathrm{pH}$ as (Lee et al., 2009) states that hydrolysis and acidogenesis start at 5.5 and $6.5 \mathrm{pH}$ respectively. However, study (Kim et al., 2003) shows that methane potential is higher between 5.5-8.5 $\mathrm{pH}$ while other studies shows narrow range of $\mathrm{pH}$ around 7-8 (Seadi et al., 2008). The acid forming bacteria require $\mathrm{pH}$ between 6-7 while methanogenic micro-organisms require $\mathrm{pH} 7-8$ (Angelidaki and Sanders, 2004). It was decided to put two bio-reactors in series to carry out the AD process for hydrolysis and acidogenesis at mesophilic temperature while acetogenesis and methanogenesis at thermophilic temperature.

Bio-reactors are also classified on temperature regimes. Three different temperature regimes i.e. psychrophilic, mesophilic, and thermophilic were maintained during anaerobic digestion. Table-1 shows the difference between these three regimes for $\mathrm{AD}$ processes. The study comprises of the theoretical calculation of mesophilic and thermophilic temperature regimes for anaerobic digestion of banana waste. Moreover, the small change in temperature causes severe problems particularly for thermophilic systems. The formation of $\mathrm{NH}_{3}$ is another important factor for temperature at $55^{\circ} \mathrm{C}$. The production of $\mathrm{NH}_{3}$ is influenced by $\mathrm{C} / \mathrm{N}$ ratio, thus increasing the $\mathrm{pH}$ up to 8.5 , having toxic effect. Thus, it is vitally important to study the kinetics of $\mathrm{AD}$ process at three different temperature regimes.

\section{Material and Methods}

In the study, the banana waste feed input rate was adjusted at $100 \mathrm{~kg} /$ day. The volume of mesophilic reactor was calculated for 15 days hydraulic retention time (HRT) and thermophilic for 10 days retention 
time. AD process can be categorized into two i.e. wet anaerobic and dry anaerobic digestions depending upon the total solids (TS) in the feedstock. The nature of bio-chemical reactions is intricate due to nonlinearity and multistage biodegradability of biowaste (Donoso et al., 2011). Housagul et al., 2014 studied the co-gestion studied methane and hydrogen production from banana peel by two phases AD process. Bardiya et al., 1996 studied the methane production rate for banana peel and pineapple at different hydraulic retention time. However, Tumutegyereize et al., 2011 studied the biogas production based on particle size distribution for various kinds of banana peel. Table-2 shows the proximate analysis for banana waste which are the required indicators for effective calculation of methane potential from banana waste.

Table-1. Comparison of three temperature regimes for $A D$ process

\begin{tabular}{|l|c|c|c|}
\hline $\begin{array}{l}\text { Process } \\
\text { Indicators }\end{array}$ & Psychrophilic & Mesophilic & Thermophilic \\
\hline $\mathrm{pH}$ & $4.5-6$ & $5.5-6.5$ & $7-8.5$ \\
\hline Temperature & $<25^{\circ} \mathrm{C}$ & $32-40^{\circ} \mathrm{C}$ & $50-60^{\circ} \mathrm{C}$ \\
\hline $\begin{array}{l}\text { Sensitivity to } \\
\text { temperature }\end{array}$ & $\begin{array}{l}\text { Very less } \\
\text { sensitive }\end{array}$ & Sensitive & Very sensitive \\
\hline $\begin{array}{l}\text { Bacterial } \\
\text { growth rate }\end{array}$ & Small growth & $\begin{array}{c}\text { Moderate } \\
\text { growth }\end{array}$ & High growth \\
\hline $\begin{array}{l}\text { Hydraulic } \\
\text { retention time }\end{array}$ & $70-80$ days & $35-40$ days & $15-20$ days \\
\hline $\begin{array}{l}\text { Biogas } \\
\text { Potential }\end{array}$ & Very small & Moderate & High \\
\hline NH3 formation & No & Less & High \\
\hline $\begin{array}{l}\text { Reaction } \\
\text { intensity }\end{array}$ & Slow & Moderate & High \\
\hline $\begin{array}{l}\text { Reactor } \\
\text { volume }\end{array}$ & Very large & Moderate & Small \\
\hline
\end{tabular}

Table-2: Proximate analysis for banana waste (Divyabharathi et al., 2017)

\begin{tabular}{|l|c|c|c|}
\hline \multirow{2}{*}{\multicolumn{1}{|c|}{ Parameters }} & \multicolumn{3}{|c|}{ Various Banana Waste } \\
\cline { 2 - 4 } & Peel & $\begin{array}{c}\text { Pseudo } \\
\text { Stem }\end{array}$ & $\begin{array}{c}\text { Fruit } \\
\text { bunch stem }\end{array}$ \\
\hline Total solid (\%TS) & 20 & 15 & 14 \\
\hline Moisture content (\%MC) & 80 & 85 & 86 \\
\hline Volatile solid (\%VS) & 14.6 & 11.3 & 10.1 \\
\hline Ash content & 2.9 & 2.4 & 2.8 \\
\hline Fixed carbon & 1.4 & 1.2 & 0.9 \\
\hline $\begin{array}{l}\text { Total kjeldahl nitrogen } \\
\text { (mg/l) }\end{array}$ & 33 & 34.2 & 33.6 \\
\hline $\begin{array}{l}\text { Total organic carbon } \\
\text { (mg/l) }\end{array}$ & 95.8 & 94.1 & 95.2 \\
\hline \multicolumn{1}{|c|}{ C/N ratio } & 29.0 & 27.5 & 28.2 \\
\hline
\end{tabular}

Chen and Hashimoto developed a model that functions with bacterial growth rate, retention time and kinetic parameters mentioned in equation 1 was selected to estimate the methane potential for banana waste (Zainol, 2012 and Hashimoto et al., 1981).

$\gamma_{v}=\frac{B_{0} * S_{0}}{H R T}\left(1-\frac{K}{H R T * \mu_{m}-1+K}\right)$

Where; $\gamma_{\mathrm{v}}$ is $\mathrm{CH}_{4}$ production rate $\left(\mathrm{m}^{3} / \mathrm{m}^{3}\right.$.day), $\mathrm{B}_{0}$ is ultimate methane yield $\left(\mathrm{m}^{3} / \mathrm{kg}\right.$ VS), $S_{0}$ is initial concentration in terms of volatile solid $\left(\mathrm{kg} \mathrm{VS} / \mathrm{m}^{3}\right), \mu_{\mathrm{m}}$ is bacterial growth rate $\left(\right.$ day $\left.^{-1}\right)$, and $\mathrm{K}=$ first order constant. The above equation is the most utilized equation for measuring methane production rate. The bacterial growth rate and first order constant can be explained by the following equation.

$\mu_{\mathrm{m}}=0.013 \mathrm{~T}-0.129$
$\mathrm{~K}=0.6+0.0206 * \mathrm{e}^{(0.051 * \mathrm{~s} 0)}$

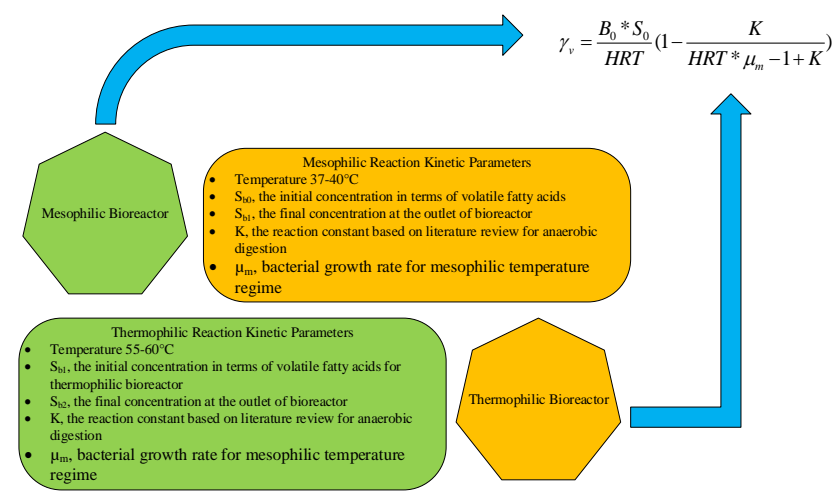

$\longrightarrow$ 15 Days HRT $\longrightarrow$

Figure-1. Graphical Representation of Methodology

The kinetic model was used for the calculation of methane content. The wet AD process was considered for theoretical calculation of methane with $80 \%$ water content and $20 \%$ banana waste. Figure- 1 shows the graphical representation of methodology while figure2 shows the technical approach for digestion of banana waste. The volumes of bioreactors were calculated that was based on $70 \%$ water content and HRT. The mesophilic reactor operated at $37-40^{\circ} \mathrm{C}$ for 15 days HRT and thermophilic reactor at $55-60^{\circ} \mathrm{C}$ for 10 days 
HRT with a $\mathrm{pH}$ range of 5.5-6.5 and 6.8-7.5, respectively. To investigate the propagation of metabolic reactions over a period of 15 days mesophilic AD and 10 days for thermophilic AD. We conducted these three experiments on $100 \mathrm{~kg} / \mathrm{day}$ banana waste including stem, fruit stem, and peel under Chen \& Hashimoto kinetic model.

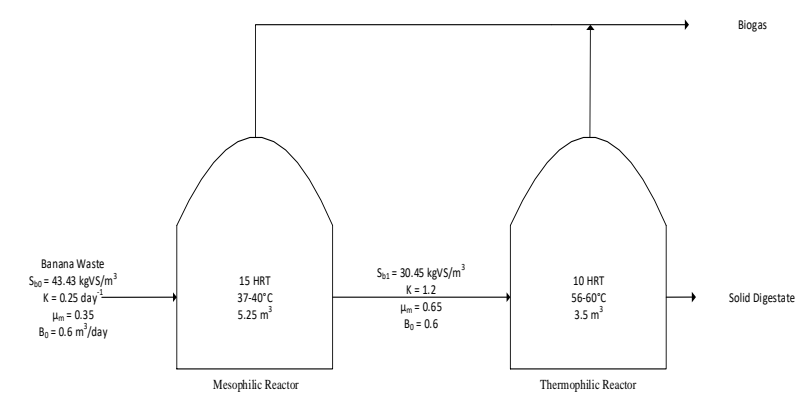

Figure-2. Flow scheme for kinetic model with key indicators

\section{Results and Discussion}

The AD process was carried out in continuously stirred tank reactor by adding $100 \mathrm{~kg} / \mathrm{day}$ of banana waste. The TS present in the banana waste is $20 \%$ $(20 \% * 100=20 \mathrm{~kg} /$ day $)$. The water content for this study was maintained at $80 \%(100 * 0.7 / 0.20)$ by providing 350 liters of water. The total amount of water for dilution is (350-100) 250 liters. Hence, the feed input is $350 \mathrm{~kg} / \mathrm{day}$. The volume of both bioreactors was calculated by the equation 4 , while the other information is given in Table- 3 .

$\mathrm{V}=\mathrm{Q}^{*} \mathrm{HRT}$

Table-3: Bioreactor process information

\begin{tabular}{|l|c|c|c|}
\hline AD Process & $\begin{array}{c}\text { HRT } \\
\text { Days }\end{array}$ & $\begin{array}{c}\text { Temperature } \\
{ }^{\circ} \mathbf{C}\end{array}$ & $\begin{array}{c}\text { Rector Volume } \\
\mathbf{~ m}^{\mathbf{3}}\end{array}$ \\
\hline Mesophilic & 15 & $37-40$ & 5.25 \\
\hline Thermophilic & 10 & $55-60$ & 3.5 \\
\hline
\end{tabular}

Literature review suggests that total solid (TS) or dry matter content of banana waste is supposed to be $20 \%$ and volatile solid (VS) is $87 \%$ of TS (Reddy and Yang, 2015). The VS is $17.4 \mathrm{Kg}$. The calculation for the biodegradable factor of the input material is based on lignin content (LC). Typically, lignin content of banana waste is around 17\% (Oliveira et al., 2016).
Thus;

Biodegradable fraction $=0.83-0.028 \mathrm{LC}=0.82524$

The initial concentration in terms of volatile solid in the banana waste is given below;

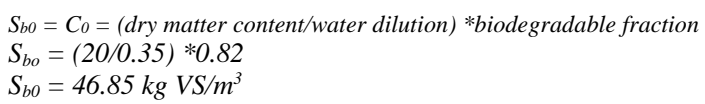

The outlet concentration of bio-waste is calculated by the following formula

$S_{e}=(1$-biodegrable fraction $) * S_{b 0}$

Since the system was designed with two stage anaerobic reactor, in first stage reactor (mesophilic) digestion of banana waste occurred up to $35 \%$ while it reached $45 \%$ in second stage thermophilic reactor.
$S_{b 1}=(1-0.35) * 46.82$
$S_{b 1}=30.433 \mathrm{~kg} \mathrm{VS} / \mathrm{m}^{3}$
$S_{b 2}=(0.65-0.45) 30.433$
$S_{b 2}=6.1 \mathrm{~kg} \mathrm{VS} / \mathrm{m}^{3}$
(First stage reactor)
(Second stage reactor)

Table-4: Predicted biomethane using kinetic model

\begin{tabular}{|c|c|c|c|c|c|c|c|}
\hline $\begin{array}{c}\text { Key } \\
\text { Indicators }\end{array}$ & $\begin{array}{c}\mathbf{B}_{\mathbf{0}} \\
\mathbf{m}^{\mathbf{3}} / \mathbf{k g} \\
\mathbf{V S}\end{array}$ & $\begin{array}{c}\mathbf{S}_{\mathbf{b}} \\
\mathbf{k g} \\
\mathbf{V S} / \mathbf{m}^{\mathbf{3}}\end{array}$ & $\begin{array}{c}\mathbf{S}_{\mathbf{b} 1} \\
\mathbf{k g} \\
\mathbf{V S} / \mathbf{m}^{3}\end{array}$ & $\begin{array}{c}\mathbf{K} \\
--\end{array}$ & $\begin{array}{c}\boldsymbol{\mu}_{\mathbf{m}} \\
/ \mathbf{d a y}\end{array}$ & $\begin{array}{c}\mathbf{\gamma}_{\mathbf{v}} \\
\mathbf{m}^{3} / \mathbf{m}^{\mathbf{3}} \mathbf{d} \\
\mathbf{a y}\end{array}$ & $\begin{array}{c}\gamma_{\mathbf{v}} \\
\mathbf{m}^{\mathbf{3}} / \mathbf{d a} \\
\mathbf{y}\end{array}$ \\
\hline Mesophilic & 0.60 & 46.85 & -- & 0.25 & 0.35 & 1.76 & 9.24 \\
\hline $\begin{array}{c}\text { Thermophi } \\
\text { lic }\end{array}$ & 0.60 & -- & 30.43 & 1.2 & 0.65 & 1.54 & 5.4 \\
\hline
\end{tabular}

Table-4 shows the key indicators obtained for theoretical calculation of biogas. For mesophilic, the first order degradation constant is 0.25 per day. According to our experimental results initially $10 \mathrm{~kg}$ of wet waste produces $1 \mathrm{~m}^{3}$ of biogas which means 0.6 $\mathrm{m}^{3}$ of methane gas is produced at $60 \%$ water content. The value for concentration was calculated using equation 5 and 6 . The initial whereas equation 6 was used to calculated concentration of the substrate. The first order reaction constant for mesophilic reactor was $0.25 \mathrm{day}^{-1}$ and for thermophilic temperature regime, the value of $\mathrm{K}$, calculated using equation 3 at temperature $60^{\circ} \mathrm{C}$. The predicted methane production rate was calculated based on parameters mentioned in the Table-4. Equation 4 was utilized to calculate $\gamma_{v}$ in $\mathrm{m}^{3} /$ day.

The above-mentioned model was used to estimate the 
methane production rate for banana waste anaerobic digester. The methane production rate obtained by considering key parameters like HRT, VFA concentration, temperature, bacterial growth and kinetic rate constant. The methane production was estimated $14.6 \mathrm{~m} 3 /$ day using $100 \mathrm{~kg} /$ day of banana waste which means ultimate methane yield is 0.365 $\mathrm{m} 3 / \mathrm{kg}$ VS for mesophilic AD. Table-5 shows that the results obtained from the study present an encouraging scenario in view of published data.

Table-5: Comparison of predicated methane yield with previous reported literature

\begin{tabular}{|l|c|c|c|}
\hline \multicolumn{1}{|c|}{ Substrate } & Process & $\begin{array}{c}\text { Methane } \\
\text { Yield } \\
\mathbf{m}^{\mathbf{3}} / \mathbf{k g ~ V S}\end{array}$ & Reference \\
\hline $\begin{array}{l}\text { Banana Waste } \\
\text { (stem, fruit stem, } \\
\text { peel and leaves) }\end{array}$ & $\begin{array}{c}\text { Mesophilic AD } \\
15 \text { days; } 37-40^{\circ} \mathrm{C}\end{array}$ & 0.365 & This study \\
\hline $\begin{array}{l}\text { Banana Waste } \\
\text { (stem, fruit stem, } \\
\text { peel and leaves) }\end{array}$ & $\begin{array}{c}\text { Thermophilic AD } \\
10 \text { days; 55-60 }{ }^{\circ} \mathrm{C}\end{array}$ & 0.395 & This study \\
\hline Red Banana Peel & $\begin{array}{c}\text { Anaerobic } \\
\text { Digestion }\end{array}$ & 0.322 & $\begin{array}{c}\text { (Gunaseelan, } \\
\text { 2004) }\end{array}$ \\
\hline Banana Unpeel & $\begin{array}{c}\text { Anaerobic } \\
\text { Digestion }\end{array}$ & 0.349 & $\begin{array}{c}\text { (Khan et al., } \\
\text { 2016) }\end{array}$ \\
\hline Banana Peel & $\begin{array}{c}\text { Batch Type } \\
\text { Digestor } \\
21 \text { days; } 55^{\circ} \mathrm{C}\end{array}$ & 0.289 & $\begin{array}{c}\text { (Buffière et al., } \\
\text { 2006) }\end{array}$ \\
\hline Banana Peel & $\begin{array}{c}\text { Batch Type } \\
\text { Digestor } \\
35 \text { days; } 37^{\circ} \mathrm{C}\end{array}$ & 0.294 & $\begin{array}{c}\text { (Tumutegyerei } \\
\text { ze et al., 2011) }\end{array}$ \\
\hline $\begin{array}{l}\text { Banana waste } \\
\text { (peduncle + green } \\
\text { banana) }\end{array}$ & $\begin{array}{c}\text { Fed Batch Digestor } \\
70 \text { days; } 38^{\circ} \mathrm{C}\end{array}$ & 0.398 & $\begin{array}{c}\text { (Clarke et al., } \\
\text { 2008) }\end{array}$ \\
\hline
\end{tabular}

The predicted amount of methane obtained from mesophilic reactor replicates the most accurate results obtained from Chen \& Hashimoto kinetic model compared to thermophilic AD process. The bacterial growth rate for thermophilic reactor recorded during this experiment was significantly different from that calculated using equation 2 , reported in literature and observed during pilot plant studies (Karthikeyan et al., 2018). Overall study represents the state-of-art procedure to calculate the biomethane potential in a theoretical way based on ultimate and proximate analysis of any kind of biomass.

Furthermore, these calculations predict that in Pakistan banana waste has potential to generate $273854 \mathrm{kWh}$ of electricity annually if the bio-reactors works on its $60 \%$ efficiency. The study comprises of theoretical calculation for mesophilic and thermophilic temperature regimes. The kinetic study recorded most accurate methane production for mesophilic bioreactor compared to thermophilic bioreactor (Hamzah et al., 2019). On contrary, thermophilic reactor produces more biogas as methane bacteria survive on this temperature regime, thus, producing greater amount of biogas. The reaction constant and bacterial growth rate for thermophilic temperature regimes are considerably high but no such data was available before.

\section{Conclusion}

Kinetic $\mathrm{AD}$ process is a complex bio-chemical process which involves metabolic reactions in series. The kinetic model is the most optimal way to measure the production of methane based on lignocellulose properties, temperature, and bacterial growth. The Chen \& Hashimoto model is a state-of-the-art model which predicts higher amount of methane for mesophilic temperature regimes only. The total amount of methane obtained from the model is 14.6 $\mathrm{m}^{3} /$ day. The amount of methane predicted by this model is accurate for mesophilic reactor but the methane production for thermophilic reactor is very low which is not in accordance with the published data. However, other studies show that thermophilic temperature regime gives highest amount of methane as compared to mesophilic temperature regime. The model gives low amount of methane production for thermophilic systems because of inaccuracy in bacterial growth rate. Thus, the model can be optimized by using special analytical techniques to determine bacterial growth of thermophilic bioreactors. The parameters used in this model were adopted from already observed and published data. This paper is helpful for the theoretical estimation of biogas production from other fruit wastes as well.

\section{Acknowledgement}

The authors acknowledge the editorial board, peer reviewers for their review during the time of COVID19. The authors are thankful to PMAS Arid Agriculture University Rawalpindi, Pakistan for providing the platform and financial support for this study. 
Disclaimer: None.

Conflict of Interest: None.

Source of Funding: PMAS Arid Agriculture

University Rawalpindi, Pakistan

\section{References}

Angelidaki I and Sanders W, 2004. Assessment of the anaerobic biodegradability of macropollutants. Rev. Environ. Sci. Biotechnol. 3: 117-129.

APP, 2016. Pakistan producing 154,825-ton banana annually. https://www.pakistantoday.com.pk/2016/12/27/p akistan-producing-154825-ton-banana-annually/

Bardiya N, Somayaji D and Khanna S, 1996. Bio methanation of banana peel and pineapple waste. Bioresour. Technol. 58(1): 73-76.

Barros AR, De Amorim, Reis ELC, Shida CM, GM and Silva EL, 2010. Biohydrogen production in anaerobic fluidized bed reactors: Effect of support material and hydraulic retention time. Int. J. Hydrog. Energ. 35(8): 3379-3388.

Bhushan S, Rana MS, Nandan N and Prajapati SK, 2019. Energy harnessing from banana plant wastes: A review. Bioresour. Technol. Rep. 7: 100212.

Buffière P, Loisel D, Bernet N and Delgenes JP, 2006. Towards new indicators for the prediction of solid waste anaerobic digestion properties. Water Sci. Technol. 53(8): 233-241.

Capuano L, 2018. International energy outlook 2018 (IEO2018). US Energy Information Administration (EIA), Washington DC, USA.

Clarke WP, Radnidge P, Lai TE, Jensen PD and Hardin MT, 2008. Digestion of waste bananas to generate energy in Australia. J. Waste Manage. 28(3): 527-533.

Divyabharathi R, Angeeswaran R, Jagadeeshkumar K and Pugalendhi S, 2017. Characterization and Batch Anaerobic Digestion Study of Banana Wastes. Int. J. Curr. Microb. Appl. Sci. 6: 23072315.

Donoso-Bravo A, Mailier J, Martin C, Rodríguez J, Aceves-Lara CA and Wouwer AV, 2011. Model selection, identification and validation in anaerobic digestion: A Review. Water Res. 45: 5347-5364.

FCCC (Framework Convention of Climate Change), 2015. Reports of the conference of the parties on its twenty first session, November to 13 December 2015, Paris, France.
Gunaseelan VN, 2004. Biochemical methane potential of fruits and vegetable solid waste feedstocks. J. Biomass Bioenerg. 26: 389-399.

Hamzah MAF, Jahim JM and Abdul PM, 2019. Comparative start-up between mesophilic and thermophilic for acidified palm oil mill effluent treatment. In IOP Conference Series: Earth Environ. Sci. 268(1): 012028.

Hashimoto A, Chen Y and Varel V, 1981. Theoretical aspects of methane production: state of-the-art in livestock waste: a renewable resource, pp. 86-95. In Proceedings, $4^{\text {th }}$ International Symposium on Livestock Wastes. 15-17 April 1981, Amarillo Civic Center, Amarillo, Texas.

Housagul S, Sirisukpoka U, Boonyawanich S and Pisutpaisal N, 2014. Biomethane production from co-digestion of banana peel and waste glycerol. J. Energ. Procedia. 61: 2219-2223.

Iqbal T, Ali Z, Abbas A, Hussain Z, Rafique SF, Dong CQ and Lu Q, 2019. Fast pyrolysis of agricultural residues: a sustainable way to produce clean energy (an investigation of Pakistan's agricultural biomass). J. Fresenius Environ. Bull. 28: 12641272.

Iqbal T, Dong CQ, Lu Q, Ali Z, Khan I, Hussain Z and Abbas A, 2018. Sketching Pakistan's energy dynamics: Prospects of biomass energy. J Renew. Sustain. Energ. 10(2): 023101.

Javed MS, Raza R, Hassan I, Saeed R, Shaheen N, Iqbal J and Shaukat SF, 2016. The energy crisis in Pakistan: A possible solution via biomass-based waste. J. Renew. Sustain. Energ. 8: 043102.

Karthikeyan OP, Trably E, Mehariya S, Bernet N, Wong JW and Carrere H, 2018. Pretreatment of food waste for methane and hydrogen recovery: a review. Bioresour. Technol. 249: 1025-1039.

Kashyap DR, Dadhich KS and Sharma SK, 2003. Biomethanation under psychrophilic conditions: a review. Bioresour. Technol. 87: 147-153.

Khalid A, Arshad M, Anjum M, Mahmood T and Dawson L, 2011. The anaerobic digestion of solid organic waste. J. Waste Manage. 31: 1737-1744.

Khan MT, Brulé M, Maurer C, Argyropoulos D, Müller J and Oechsner H, 2016. Batch anaerobic digestion of banana waste-energy potential and modelling of methane production kinetics. Int. J. Agric. Eng. 18(1): 110-128.

Khan MT, Maurer C, Argyropoulos D, Brule M and Mueller J, 2009. Anaerobic digestion of banana waste, a potential source of energy in Uganda. 
Proceedings Tropentag. 6-8 October 2009, University of Hohenheim, Hamburg, Germany.

Kim J, Park C, Kim TH, Lee M, Kim S, Kim SW and Lee J, 2003. Effects of various pretreatments for enhanced anaerobic digestion with waste activated sludge. J. Biosci. Bioeng, 95: 271-275.

Lee DH, Behera SK, Kim JW and Park HS, 2009. Methane production potential of leachate generated from Korean food waste recycling facilities: a lab-scale study. J. Waste Manage. 29: 876-882.

Oliveira TÍS, Rosa MF, Cavalcante FL, Pereira PHF, Moates GK, Wellner N, Mazzetto SE, Waldron KW and Azeredo HM, 2016. Optimization of pectin extraction from banana peels with citric acid by using response surface methodology. Food Chem. 198: 113-118.

Reddy N and Yang Y, 2015. Innovative biofibers from renewable resources. Springer-Verlag Berlin, Heidelberg, Germany.

Seadi TA, Rutz D, Prassl H, Kottner M, Finsterwalder T, Volk S and Janssen R, 2008. Biogas Handbook, University of Southern Denmark, Esbjerg, Denmark.

Stams AJM, Plugge CM, De Bok FAM, Van Houten BHGW, Lens P, Dijkman H and Weijma J, 2005. Metabolic interactions in methanogenic and sulfate-reducing bioreactors. J. Water Sci. Technol. 52: 13-20.
Tumutegyereize P, Muranga FI, Kawongolo $\mathrm{J}$ and Nabugoomu F, 2011. Optimization of biogas production from banana peels: effect of particle size on methane yield. Afr. J. Biotechnol. 10 (79): 18243-18251.

Zainol N, 2012. Kinetics of biogas production from banana stem waste, pp. 395-408. Öchsner A, FM da Silva L, Altenbach H, Analysis and Design of Biological Materials and Structures. Springer, Berlin, Heidelberg, Germany.

\section{Contribution of Authors}

Aneeq: Conceived idea, ran model, data collection, data analysis, and manuscript write up

Iqbal T: Designed research methodology and data interpretation and manuscript write up

Ali Z: Helped in literature review and manuscript write up

Shah SJA: Helped in literature review and manuscript write up

Abbas A: Helped in literature review and manuscript corrections

Afzal A: Helped in data analysis and data interpretation

Cheema MJM: Involved in designing research methodology and manuscript corrections 